\title{
Fourier analysis of the planktonic foraminifer Neogloboquadrina pachyderma (Ehrenberg) from the Pleistocene Santa Barbara Formation, California
}

\author{
CHIA-CHEN YEH ${ }^{1}$, R. 'TIMOTHY PATTERSON² \& ROBERT H. OSBORNE ${ }^{1}$ \\ ${ }^{1}$ Department of Geological Sciences, University of Southern California, Los Angeles, California. 90089. U.S.A. \\ ${ }^{2}$ Department of Earth Sciences, Carleton University, Ottawa, Ontario K1S 5B6, Canada
}

\begin{abstract}
A Fourier analysis was performed on three hundred and fifty two specimens of Neogloboquadrina pachyderma, obtained from eleven sedimentary rock samples of the Pleistocene Santa Barbara Formation. Statistical analytical methods, including Chi square values, Q-mode cluster analysis, Q-mode factor analysis and discriminant function classification, were also carried out on these specimens.

Two natural groups are recognized which can be correlated with the assemblages previously defined as warm and cool Neogloboquadrina pachyderma phenotypes, as recognized by microscope. The amplitude values of the second, third, fourth, and seventh harmonics of the warm phenotype specimens are greater than those of the cool phenotype specimens. On the other hand, the amplitude values of the fifth harmonic of the warm phenotype specimens are less than those of the cool phenotype specimens. Only the second harmonic is statistically significant in describing the shape differences between the warm and cool phenotypes. Increased compaction of the cool phenotype tends to decrease elongation. resulting in low amplitude values for the second harmonic. An intergradational form between the warm and cool water phenotypes comprises 9.4 percent of the specimens.

This intergradation, albeit narrow, identified by Fourier analysis and the discriminant function indicates that the controlling factors in the shape variation of the test are local, and are caused by variation in seasonal surface circulation patterns. The warm and cool water phenotypes of Neogloboquadrina pachyderma are therefore ecophenotypic varients within a single species.
\end{abstract}

\section{INTRODUCTION}

The upper Miocene to Recent foraminifer Neogloboquadrina pachyderma (Ehrenberg) has been the subject of considerable study since the value of this species for the interpretation of past oceanographic and climatic changes was recognized by Ericson (1959) and Bandy (1960). These researchers found that dominantly sinistral (left coiling) assemblages are found in polar and subpolar areas. However, more recent studies have made the taxonomic position of this species controversial. Neogloboquadrina pachyderma was shown to have many morphological variations, not only in coiling direction, but also in test shape, and surface ultrastructure. Kennett $(1968,1969)$ recognized three morphological groups within $N$. pachyderma based on the coiling direction and number of chambers in the last whorl: sinistral, intermediate (dominantly sinistral), and dextral. Keller (1978) informally classified N. pachyderma as existing in three phenotypes; Forms 1,2, and 3 , based on the shape and size of the test. Reynolds and Thunell (1986) subdivided N. pachyderma into Group $A$ and Group $B$ based on shape of the test. In commenting on Keller's (1978) classification they determined that there is intergradation between Keller's Form 2 and 3, which they integrated into Group B, and Keller's Form 1 which correlated with their Group A. The difference between Reynold's and Thunell's (1986) Groups A and B, can be easily observed with microscopy. The test of the Group A phenotype is more compact and has secondary calcite encrustation, whereas the more inflated tests of Group B have a reticulate surface pattern with no secondary calcification. In addition, Group A forms are predominantly sinistral, whereas Group B forms are dominantly dextral.

Numerous workers, including Kennett (1968), Bandy (1972), Ingle (1973), and Kennett and Srinivasan (1980) have regarded sinistral and dextral forms on $N$. pachyderma as representing phenotypic variations within a single species. In contrast, Cifelli (1973) and Olsson (1976) considered the sinistral and dextral forms to represent separate species with self contained histories. They based their conclusions on the observation that sinistral forms tend to be thicker walled than specimens found in predominantly dextral populations (Cifelli, 1973) and because the surface ultrastructure of the calcite crust of sinistral forms is fundamentally different from that of dextral forms (Olsson, 1976). Kennett and Srinivasan (1980) countered by noting that 
there are also thin-walled sinistral forms and stating that the surface ultrastructure merely reflect differences in the degree of secondary calcification and not a specific trait. Although there has been considerable research on the ultrastructure of $N$. pachyderma, no quantitative determination has been made for other significant parameters observed in these phenotypes; i.e. morphological variation.

Since the pioneering work on Fourier analysis for grain shape by Ehrlich and Weinberg (1970), Fourier series have been applied to the shape of ostracode margins (Kaesler and Waters, 1972), zooecial shapes in fossil bryozoa (Anstey and Delmet, 1973), palynomorph shape (Mirkin and Bagdasaryan, 1972), miospore shape (Christopher and Waters, 1974), and foraminiferal shape (Belyea and Thunell, 1984; HealyWilliams and Williams, 1981; Healy-Williams, 1983). All of these studies have demonstrated that Fourier shape analysis provides an accurate and quantitative method for rapid determination of the components of test shape in microfossils.

Test shape may vary as a function of phylogenetic affinity, environmental stress and ecophenotypic variation (Healy-Williams, 1981), and thus Fourier shape analysis is a powerful tool for morphometric studies on variable species such as $N$. pachyderma. The purpose of this research is to quantitatively demonstrate the characteristic features of Reynolds and Thunell's (1986) Group A (cool water phenotype) and Group B (warm water phenotype) and to show the morphological relationship between Group A and B by appropriate statistical methods.

\section{MATERIALS AND METHODS}

There were widespread paleoclimatic and paleoceanographic fluctuations all along the California Borderland during deposition of the Santa Barbara Formation at the Bathhouse Beach locality, Santa Barbara, California, from the Middle Pleistocene (tentative $87 \mathrm{Sr} / 86 \mathrm{Sr}$ date provided by $\mathrm{R}$. Capo, pers. comm., 1989). Thus, due to the difficulty of accurately correlating samples from a wide range of latitudes, and because of the wide range of paleoceanographic and paleoclimatic conditions present at various times during deposition of the section at Bathhouse Beach (Patterson, Brunner, Capo and Dahl, in press), sampling was limited to this single locality.

Eleven rock samples were collected at intervals from the lower member of the Santa Barbara Formation (Fig. 1). The outcrop is located in a road cut along Cabrillo Boulevard beginning just south of the paved walkwav between Santa Barbara College and City Park. The highly fossiliferous beds are exposed for about 80 meters along Cabrillo Boulevard, dipping about $20^{\circ}$ south and striking perpendicular to the road, with the stratigraphically older beds exposed at the

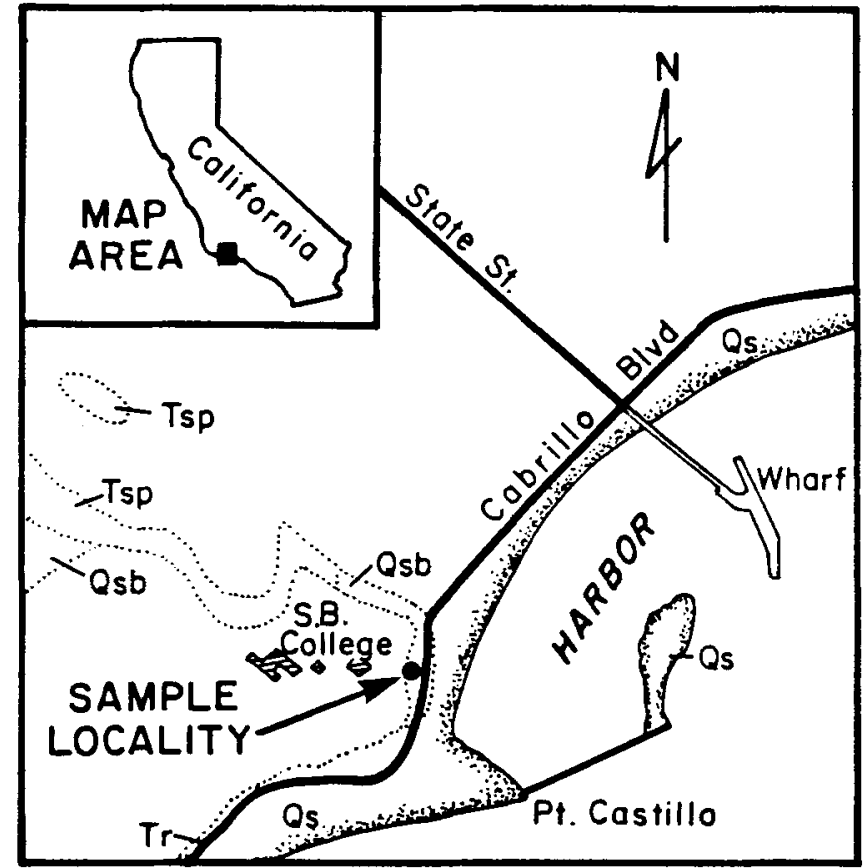

Fig. 1. Locality map showing the sample locality and distribution of the Santa Barbara Formation (Qsb).

north end of the exposure. An additional 10 meters of the sandy upper member are exposed at the south end of the cut but these were not sampled. The levels of the collected samples, as measure from the north end of the section are:

Sample 1-6.0 meters Sample 2-13.8 meters Sample 3-22.0 meters Sample 4-26.0 meters Sample 5-32.0 meters Sample 6-37.0 meters Sample 7-45.0 meters Sample 8-52.0 meters Sample 9-62.8 meters Sample 10-67.4 meters (23.1 meters dip corrected); Sample 11-71.4 meters (24.4 meters dip corrected);

In the laboratory, samples were washed over a $75 \mu \mathrm{m}$ screen and dried before examination. Of 352 specimens obtained from the eleven samples (Table 1), 204 represent the warm water phenotype (Pl. 1, figs. 1-3) and 148 represent the cool water phenotype (Pl. 1, figs. 4-8).

Fourier shape analysis was carried out on each $N$. pachyderma individual. The specimens were digitized from the dorsal side using a digital Graphic CAT-100 optical digitizer and the EDGE Fortran programme (Fogerty, 1985). The resultant matrix was converted to a data set consisting of a value for each harmonic using the Fast Fourier Transform (Brigham, 1974). Each 


\begin{tabular}{|c|c|c|c|}
\hline Sample & $\begin{array}{c}\text { Warm } \\
\text { Pheno. }\end{array}$ & $\begin{array}{c}\text { Cool } \\
\text { Pheno. }\end{array}$ & $\begin{array}{c}\text { Total } \\
\text { W8C } \\
\text { Spec. }\end{array}$ \\
\hline $\begin{array}{c}\text { Total } \\
\text { Specimens }\end{array}$ & 204 & 148 & 352 \\
\hline 1 & 20 & 9 & 29 \\
2 & 20 & 2 & 22 \\
3 & 20 & 17 & 37 \\
4 & 17 & 13 & 30 \\
5 & 20 & 8 & 28 \\
6 & 15 & 20 & 35 \\
7 & 15 & 20 & 35 \\
8 & 20 & 20 & 40 \\
9 & 20 & 19 & 39 \\
10 & 18 & 12 & 30 \\
11 & 19 & 8 & 27 \\
\hline
\end{tabular}

Table 1. The cool, warm, and total number of Neogloboquadrina pachyderma (Ehrenberg) specimens collected from each sample.

harmonic amplitude represents the relative contribution to the empirical shape of a characteristic shape component. For example, the second harmonic represents elongation, the third a trefoil, the fourth a quadrefoil, and so on.

In order to determine the statistically significant harmonics controlling the shape of this species, chi square values were calculated on the highest and lowest amplitude of the first ten harmonics respectively (Fig. 2).

Using the IMSL (1982) computer programme OCLINK, a Q-mode cluster analysis was made to compare the similarity of warm and cool phenotype specimens from the eleven sample levels utilizing the amplitudes of the first 16 harmonics (ranging from $0.0000-0.0030$ ). The warm and cool phenotype specimens in each sample were separated microscopically resulting in twenty two subsamples (Fig. 3).

A Q-mode factor analysis, using IMSL (1982) computer programme OFCOEF, was performed to determine the end members within the 22 subsamples (Table 2). A discriminate function that best separated two previously determined end-member groups was calculated by using IMSL (1982) computer programme ODNORM. The constants of the discriminant function for the two groups were then used to classify all specimens in either of the two groups using the computer programme DISCRIM.

\section{TYPE SPECIMENS}

The figured hypotypes are deposited in the U.S.

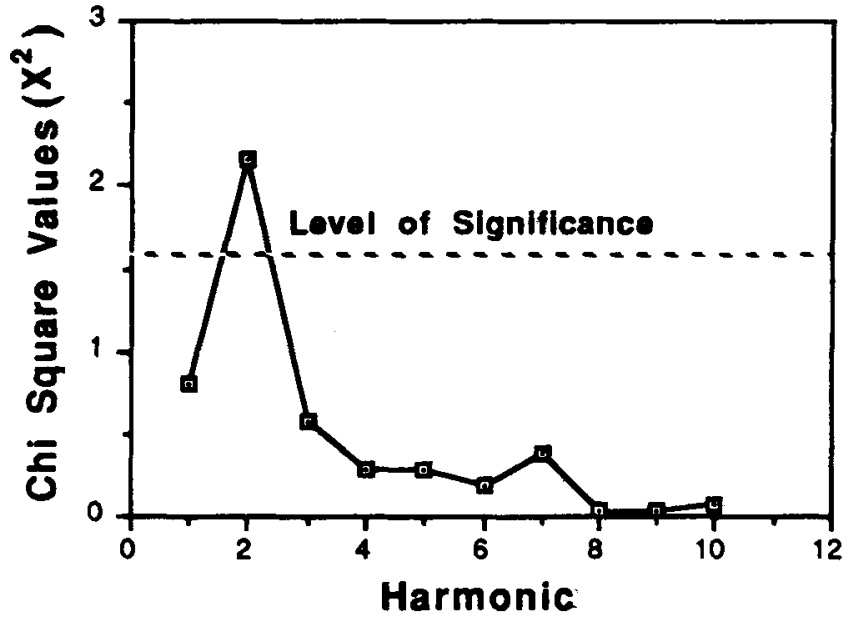

Fig. 2. Chi-square values for the first ten Fourier Analysis harmonics. Only the second harmonic is statistically significant by exceeding the critical Chi-square value of 1.64

National Museum of Natural History, Washington, D.C.

\section{RESULTS}

A Q-mode cluster analysis was used to examine the similarity of the twenty-two subsamples. The Q-mode dendrogram (Fig. 3) shows two natural groupings that can be correlated with the assemblages defined by warm and cool water phenotypes.

Figure 4 illustrates the average amplitude spectrum of the first sixteen harmonics of warm water and cool water phenotypes, respectively. The amplitude values of the second, third, fourth, and seventh harmonics of all eleven warm water phenotype subsamples are larger than those of the eleven cool water phenotype subsamples. In contrast, the amplitude values of the fifth harmonic of the eleven cool water phenotype subsamples are larger than those of the eleven warm water phenotype subsamples. The amplitude values of the remaining harmonics show no conspicuous or consistent differences.

Chi-square values were calculated to the highest and lowest amplitude of the first ten harmonics, respectively, to determine the statistically significant harmonics controlling the shape of this species. Figure 2 indicates that only the second harmonic, which measures relative elongation, is statistically significant in describing the shape difference between the warm and cool phenotype (exceeding the critical Chi-square value (0.2) of 1.64). This is similar to the results of Belyea and Thunell (1984) who found that the second and third (triangularity) harmonics best explained shape changes through time in assessing the evolutionary relationship of the planktonic foraminiferal species Pulleniatina primalis 


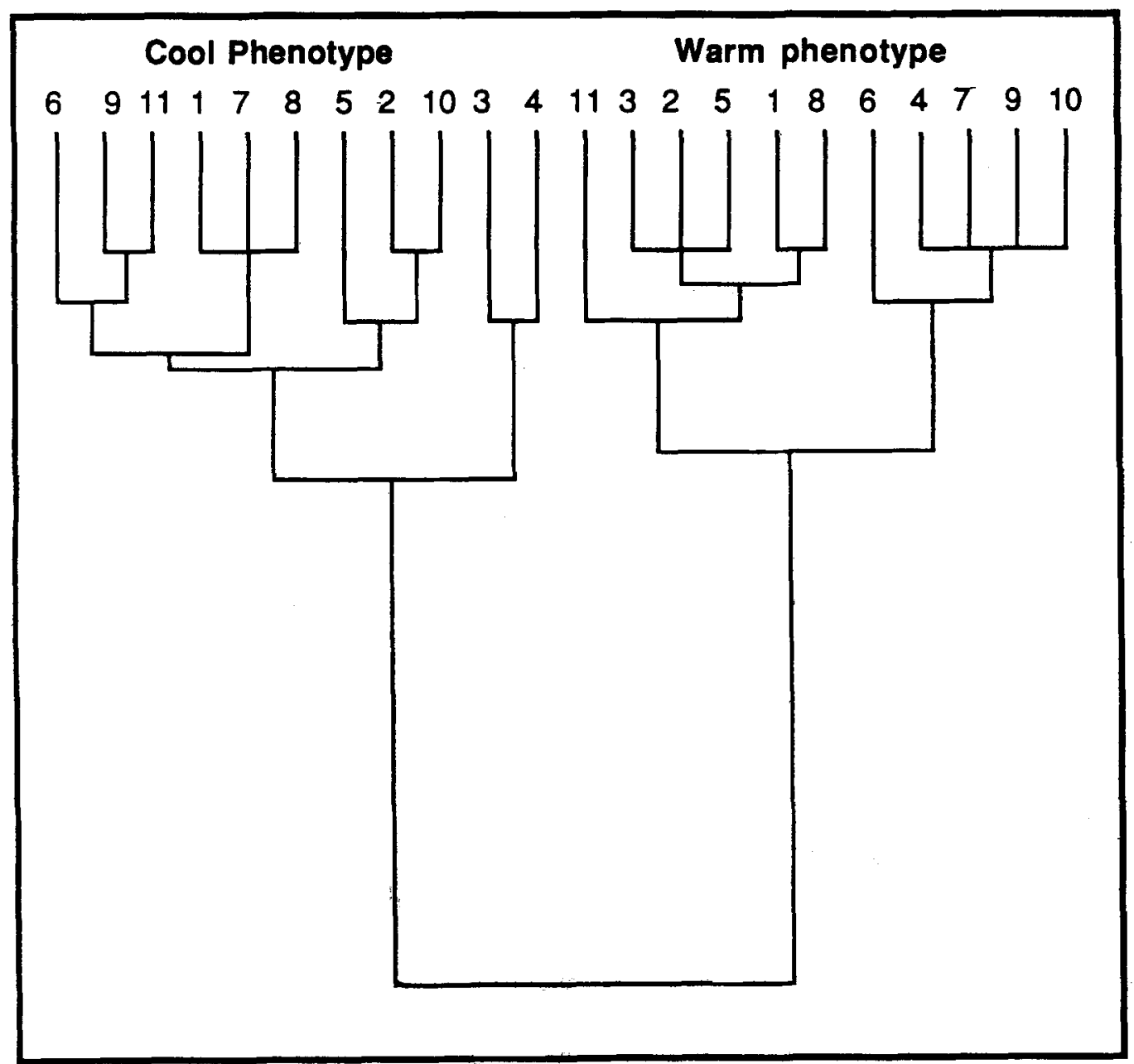

Fig. 3. Dendrogram generated by the Q-mode cluster analysis of the $22 \mathrm{cool}$ and warm Neogloboquadrina pachyderma (Ehrenberg) phenotype subsamples showing the distinctness of both phenotypes.

(Banner and Blow, 1967) and Neogloboquadrina acostaensis (Blow, 1959). The increased compact form of the cool phenotype tends to decrease the elongation, resulting in low amplitude values for the second harmonic.

A Q-mode factor analysis was performed to determine the end-members within the twenty-two subsamples. Table 1 shows that subsample 11 of the warm water phenotypes and subsample 1 of the cool phenotype are the two end-members. A discriminant function, determined by the previous two end-members, was performed on 352 specimens. Table 3 shows that 9.4 percent of the total specimens are intergradational (this includes 10.3 percent of the warm water phenotype specimens and 8.8 percent of the cool water phenotype, as recognized microscopically). Figure 4 shows the average amplitude spectrum of the intergradational

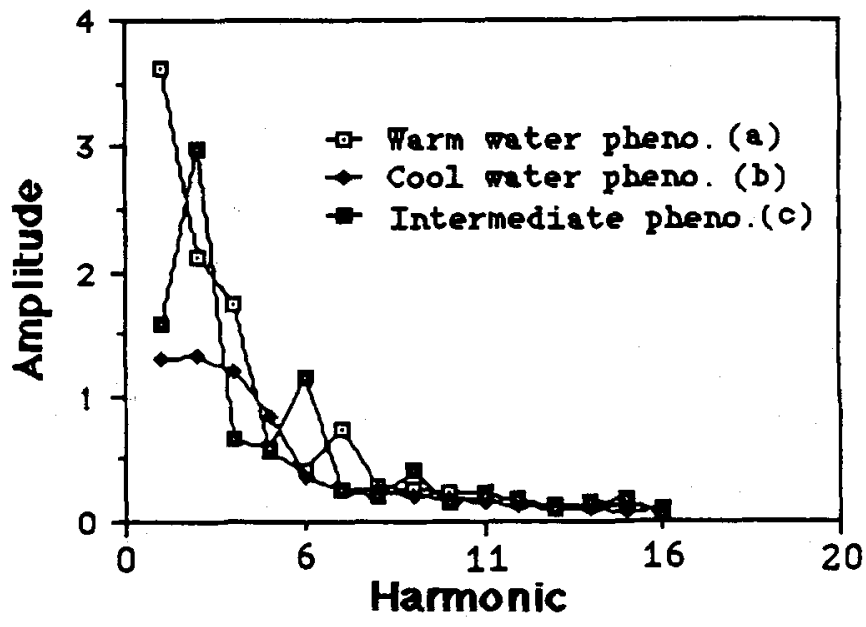

Fig. 4. The average amplitude spectrum of the first sixteen harmonics. (a) warm water phenotype, (b) cool water phenotype, and (c) intergradational phenotype. 


\begin{tabular}{|c|c|c|c|c|}
\hline \multirow{2}{*}{ Sample } & \multicolumn{2}{|c|}{ Warm Pheno. } & \multicolumn{2}{|c|}{ Cool Pheno. } \\
\hline & Factor 1 & Factor 2 & Factor 1 & Factor 2 \\
\hline $\begin{array}{c}1 \\
2 \\
3 \\
4 \\
5 \\
6 \\
7 \\
8 \\
9 \\
10 \\
11\end{array}$ & $\begin{array}{l}-0.6887 \\
-0.6763 \\
-0.6924 \\
-0.6763 \\
-0.7051 \\
-0.6267 \\
-0.6908 \\
-0.6873 \\
-0.6975 \\
-0.6935 \\
-0.7613\end{array}$ & $\begin{array}{l}-0.3124 \\
-0.3249 \\
-0.3088 \\
-0.3249 \\
-0.2960 \\
-0.3745 \\
-0.3103 \\
-0.3139 \\
-0.3036 \\
-0.3076 \\
-0.2396\end{array}$ & $\begin{array}{l}-0.2727 \\
-0.3395 \\
-0.3951 \\
-0.4334 \\
-0.2861 \\
-0.3404 \\
-0.2752 \\
-0.2938 \\
-0.2971 \\
-0.3198 \\
-0.3308\end{array}$ & $\begin{array}{l}-0.7283 \\
-0.6617 \\
-0.6062 \\
-0.5680 \\
-0.7150 \\
-0.6608 \\
-0.7258 \\
-0.7073 \\
-0.7040 \\
-0.6814 \\
-0.6704\end{array}$ \\
\hline
\end{tabular}

Table 2. Results of the Q-mode factor analysis showing that the warm water phenotype specimens of subsample 11 , and the cool water phenotype specimens of subsample 1 are the two end members of the 22 subsamples.

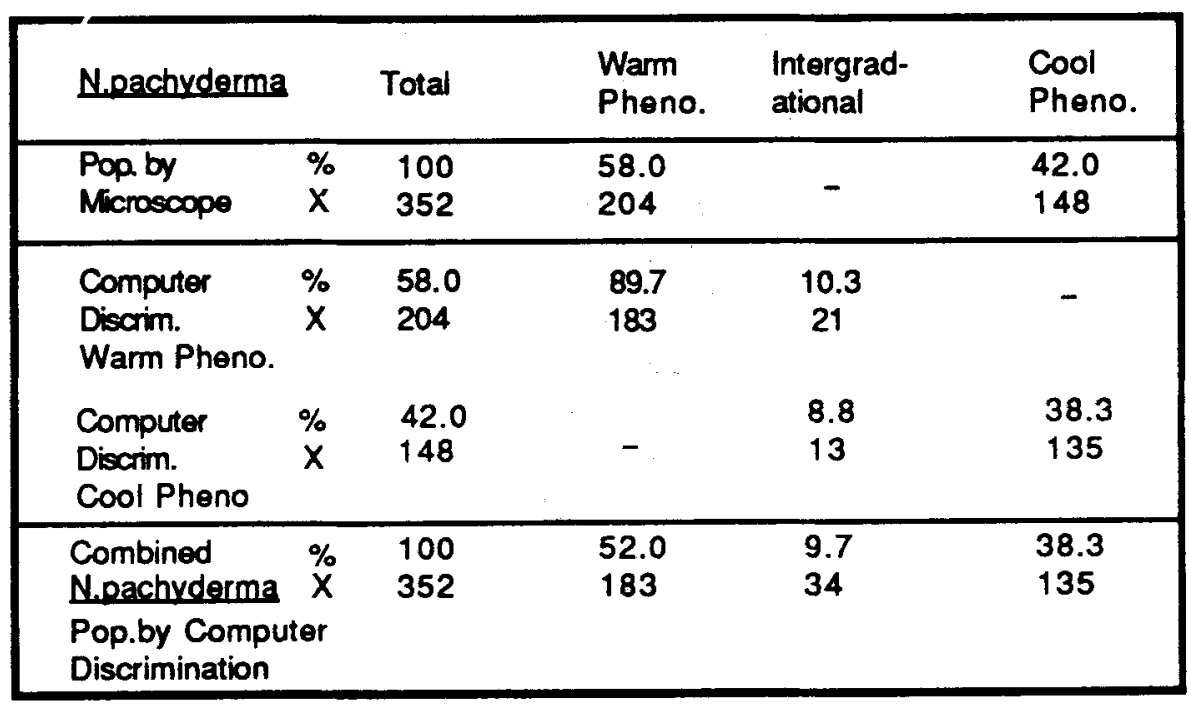

Table 3. Comparison of results obtained by light microscopy and by the discriminant function.

specimens. The intergradational specimens illustrated in PI. 2, figs. 1-6, were classified microscopically as cool water phenotypes. The amplitude value of the second harmonic is a little larger than that observed for the average cool water phenotype. The amplitude value of the third harmonic of the intergradational form is closer to that of the warm water phenotype.

\section{DISCUSSION}

At least two important controversies involve the phenotypic variation of $N$. pachyderma. The first question is whether the controlling factors for the morphological variation are latitude, and surface water temperature, or local seasonal surface circulation patterns. Kennett (1968) and Malmgren \& Kennett
(1972) discussed latitude and surface water temperature as a controlling factor in the morphological variation seen in this species in the southern oceans. Stehman (1972), who studied $N$. pachyderma from Baffin Bay in the North Atlantic, also pointed out that different morphotypes of $N$. pachyderma prefer, and are geographically distributed in association with, specific water masses. Reynolds \& Thunell (1986) further demonstrated that the morphological variation of $N$. pachyderma in the northeast Pacific relates to seasonal changes in local hydrology, with Group A being abundant when surface water temperatures are less than $8^{\circ} \mathrm{C}$ and Group $\mathrm{B}$ being abundant when surface water temperatures are greater than $8^{\circ} \mathrm{C}$. We suggest that the presence of intergradational specimens 
(comprising 9.4 percent of the population, as identified by Fourier analysis and discriminant function) in samples from the Santa Barbara Formation also indicates that the factors controlling test shape are local and caused by seasonal surface circulation patterns, with the intergradational form occurring in transitional water masses. Unfortunately, oxygen isotopic data which may have proven this hypothesis conclusively had to be discarded (J. Dahl, pers. comm.) due to the influence of meteoric water.

The causes of coiling preference is still not known. Bandy (1960) speculated that biochemical processes in the genes affected by temperature might be responsible for the different coiling ratios. On the other hand, a possible relationship to the reproduction cycle has been suggested by Tolderlund \& Bé (1971) and Thiede (1971).

The second question is whether sinistral and dextral forms are conspecific, temperature controlled variations or whether two separate species are involved. As mentioned above, Cifelli (1973) found that Sinistral forms tend to be thicker walled than dextral ones and Olsson (1976) observed that the surface ultrastructure of the calcite crust of sinistral forms differs from that of dextral forms. They proposed that the sinistral and dextral forms represent distinct species. On the other hand, Kennett \& Srinivasan (1980) considered sinistral and dextral forms of $N$. pachyderma to represent phenotypic variation within a single species, as thin walled sinistral forms occur and the surface structure ultrastructure differences reflect the degree of secondary calcification. However, they did not explain the reason for the distinct morphological characteristics of the test shape. Reynolds \& Thunell (1986) also confirmed that there are distinct morphological differences between Group A and Group B. The advantage of Fourier analysis is that the shape of the test can be calculated quantitatively. In fact, the 9.4 percent of specimens that were intergradational between Groups $A$ and $B$ were not readily recognizable by light microscope.

\section{CONCLUSIONS}

The Q-mode cluster analysis indicates that two natural groups can be correlated with the assemblages defined by the warm water phenotype and cool water phenotype of $N$. pachyderma. The amplitude values of the second, third, fourth, and seventh harmonic of the warm water phenotypes are greater than those of the cool water phenotypes. In contrast, the amplitude values of the fifth harmonic of the warm phenotypes are less than those of the cool phenotypes. However, Chi-square values indicate that the second harmonic measuring elongation best describes the difference between the two phenotypes.

The existences of an intergradational form comprising 9.4 percent of the specimens indicates that the controlling factors on the shape variation of the test of $N$. pachyderma are local and due to variation in seasonal surface circulation patterns, and thus the warm water phenotype and cool water phenotype are morphological variations within a single species.

\section{ACKNOWLEDGEMENTS}

This research was supported by an American Chemical Society Postdoctoral fellowship to RTP under ACS PRF Grant 16479-AC2 to Helen Tappan Loeblich and Alfred R. Loeblich, Jr. National Science Foundation Grant EAR-8306170 to A.R.L. and H.T.L. provided additional support and use of the scanning electron microscope. We would like to thank A.R.L., H.T.L., and David Bottjer for critically reviewing the manuscript.

\section{Manuscript received April 1988 \\ Revised manuscript accepted December 1988}

\section{Explanation of Plate 1}

Figs. 1-9. Neogloboquadrina pachyderma (Ehrenberg), all $\times 250$. Figs. 1-3, hypotype U.S.N.M. 409080, from sample 1, quadrate warm water phenotype; fig. 1, umbilical view showing 'naked' reticulate surface sculpture; fig. 2, edge view; fig. 3, spiral view showing characteristic dextral coiling: figs. 4-6, hypotype U.S.N.M. 409092, from sample 7, compact cool water phenotype; fig. 4, umbilical view showing characteristic secondary calcite encrustation; fig. 5, edge view; fig. 6, spiral view showing sinistral coiling: figs. 7-9, hypotype U.S.N.M. 409093, from sample 5, a second compact cool water phenotype; fig. 7, umbilical view showing slitlike aperture and secondary calcite encrustation; fig. 8, edge view; fig. 9, spiral view showing dextral coiling. 

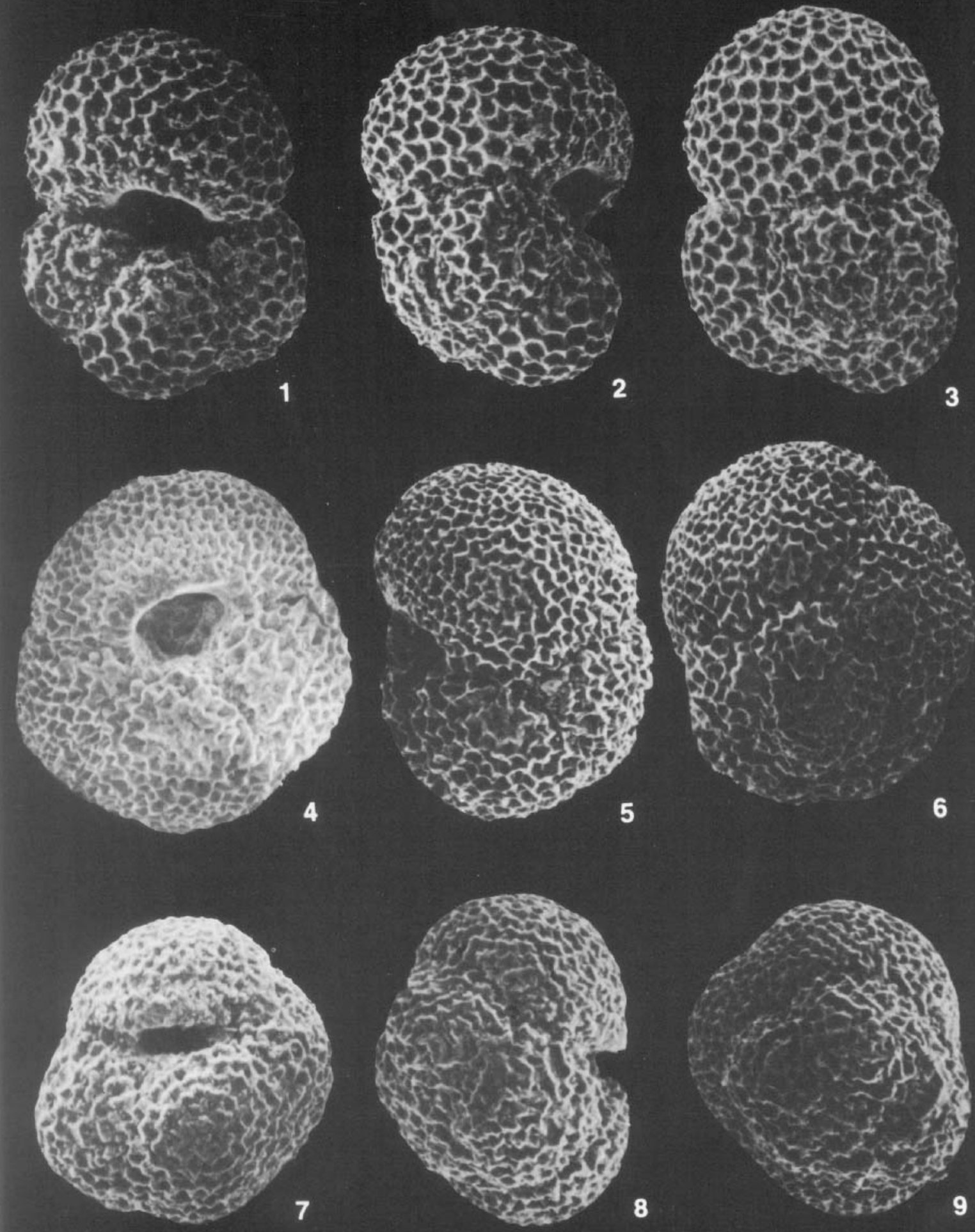


\section{REFERENCES}

Anstey, R. L. \& Delmet, D. 1973. Fourier analysis of zooecial shapes in fossil tubular bryozoans. Geol. Soc. Am. Bul., 84, 1753-1764.

Bandy, O. L. 1960. The geological significance of coiling ratios in the foraminifer Globigerina pachyderma (Ehrenberg). J. Paleont., 34, 671-681.

Bandy, O. L. 1972. Origin and development of Globorotalia (Turborotalia) pachyderma (Ehrenberg). Micropaleontology, 18, 294-318.

Banner, F. T. \& Blow, W. H. 1967. The origin, evolution and taxonomy of the foraminiferal genus Pulleniatina (Cushman, 1927). Micropaleontology, 13, 133-162.

Belyea, P. R. and Thunell, R. C. 1984 . Fourier shape analysis and planktonic foraminiferal evolution: the Neogloboquadrina-Pulleniatina lineages. J. Paleont., 58, 1026-1040.

Blow, W. H. 1959. Age, correlation and biostratigraphy of the Upper Tocuyo (San Lorenzo) and Pozon Formations, eastern Falcon, Venezeula. Bull. Am. Paleont., 38(178), 59-251.

Brigham, O. E. 1974. The Fast Fourier Transform. PrenticeHall, Inc., Englewood Cliff, New Jersey, 252 p.

Christopher, R. A. \& Waters, J. A. 1974. Fourier analysis as a quantitative descriptor of miospore shape. J. Paleont., 48, 697-709.

Cifelli, R. 1973. Observations on Globigerina pachyderma (Ehrenberg) and Globigerina incompta Cifelli from the North Atlantic Ocean. J. Foramin. Res., 3, 157-166.

Ehrenberg, C. G. 1861. Elemente des tiefen Meeresgrundes im Mexikanischen Golfstrome bei Florida; Über die Tiefgrund-Verhältnisse des Oceans am Eingange der Davisstrasse iund bei Island. K. Preuss. Akad. Wiss. Berlin, Monatsber., Berlin, 275-315.

Ehrenberg, C. G. 1873. Mikrogeologische studen über kleinste Leben der Meeres-Tiefgründe aller zonen und dessen geologischen Einfluss. K. Akad. Wiss. Berlin, Abh., Berlin, Jahrg., 1872, 131-397.

Ehrlich, R. \& Weinberg, B. 1970. An exact method for characterization of grain shape. J. Sed. Pet. 40, 205-212.

Ericson. D. B. 1959. Coiling direction of Globigerina pachyderma as a climatic index. Science, 130, 219-220.

Fogerty, T. 1985. Wavenumber filtering of gravity data and its application to interpreting structure in the western Transverse Ranges of southern California. Unpub. Masters Thesis, University of Southern California, Los Angeles, California.

Healy-Williams, N. 1983. Fourier shape analysis of Globorotalia truncatulinoides from late Quaternary sediments of the southern Indian Ocean. Marine Micropaleont. 8, 1-15.

Healy-Williams, N. \& Williams D. F. 1981. Fourier analysis of test shapes of planktonic foraminifera. Nature, 289. $485-487$
Ingle, J. C. Jr. 1973. Neogene foraminifera from the northeastern Pacific Ocean, Leg 18, Deep Sea Drilling Project. Int. Repts. Deep Sea Drilling Project. 18, 517-568.

IMSL. 1982. FORTRAN Statistical Program. IMSL Library, Dallas, Texas.

Kaesler, R. L. \& Waters, J. A. 1972. Fourier analysis of the ostracode margin. Geol. Soc. Am. Bul., 83, 1169-1178.

Keller, G. 1978. Morphologic variation of Neogloboquadrina pachyderma (Ehrenberg) in sediments of the marginal and central northeast Pacific Ocean and paleoclimatic interpretation. J. Foramin. Res., 8, 208-224.

Kennett, J. P. 1968. Latitudinal variation of Globigerina pachyderma (Ehrenberg) in surface sediments of the southwest Pacific Ocean. Micropaleontology, 14, 305-318.

Kennett, J. P. \& Srinivasan, M. S. 1980. Surface ultrastructure variation in Neogloboquadrina pachyderma (Ehrenberg): phenotypic variation and phylogeny in the Late Cenozoic. Cushman Found. Sp. Pub., 19, 134-162.

Malmgren, B \& Kennett, J. P. 1972. Biometric analysis of phenotypic variation: Globigerina pachyderma (Ehrenberg) in the South Pacific Ocean. Micropaleontology, 18, 241-248.

Mirkin, G. R. \& Bagdasaryan, L. L. 1972. The feasibility of identifying paleontological objects with the aid of optical analyzing systems. J. Paleont. 6, 103-108.

Olsson, R. K. 1976. Wall structure, topography, and crust of Globigerina pachyderma (Ehrenberg). in Takayanagi, Y. and Saito, T. (eds.). Progress in Micropaleontology: Selected Papers in honor of Prof. Kiyoshi Asano., New York, Micropaleontology Press, 244-257.

Patterson, R. T., Brunner, C. A., Capo, R. \& Dahl, J. (in press). A paleoenvironmental study of Middle Pleistocene Foraminifera of the Santa Barbara Formation, at Santa Barbara, California. J. Paleont.

Reynolds, L. A. \& Thunell, R. C. 1986. Seasonal production and morphological variation of Neogloboquadrina pachyderma (Ehrenberg) in the northwest Pacific. Micropaleontology, 32, 1-18.

Stehman, C. 1972. Planktonic foraminifera in Baffin Bay, Davis Strait and the Labrador Sea. Maritime Sediments, 8, 13-19.

Tolderlund, D. S. \& Bé, A. W. H. 1971. Seasonal distribution of planktonic foraminifera in the western North Atlantic. Micropaleontology, 17, 297-329.

Theide, J. 1971. Variations in coiling ratios of Holocene planktonic foraminifera. Deep Sea Res., 18, 823-831.

\section{Explanation of Plate 2}

Figs. 1-6. Neogloboquadrina pachyderma (Ehrenberg), all $\times 250$. Figs. 1-3, hypotype U.S.N.M. 409094, from sample 9, fig. 1, umbilical view of typical intergradational phenotype; fig. 2, edge view; fig. 3, spiral view showing sinistral coiling and secondary calcification of the compact phenotype. Figs. 4-6, hypotype U.S.N.M. 409095, from sample 9, fig. 4, umbilical view of large integradational phenotype specimen; fig. 5, edge view; fig. 6 , spiral view showing sinistral coiling and 'naked' reticulate surface sculpture. 

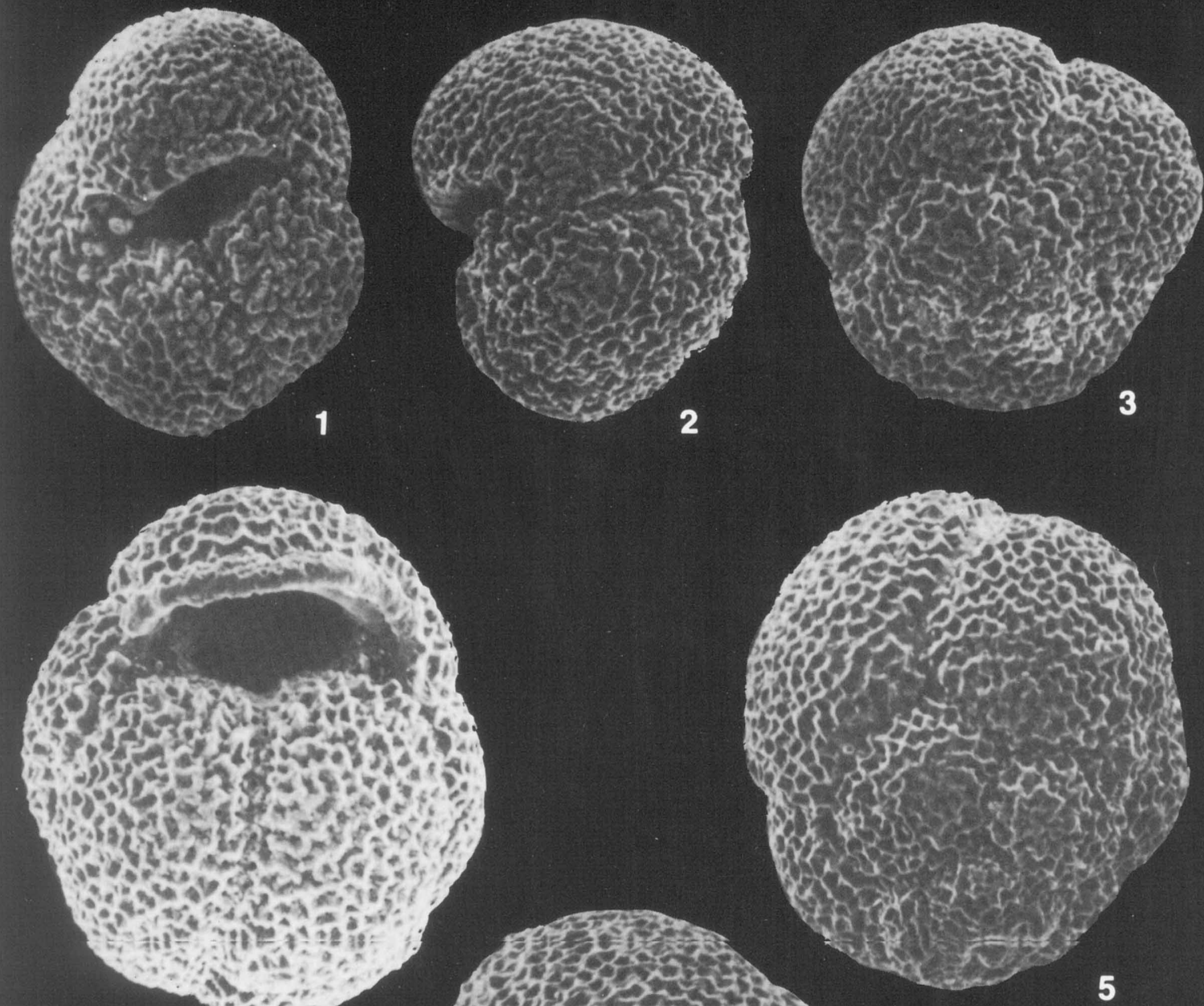

4

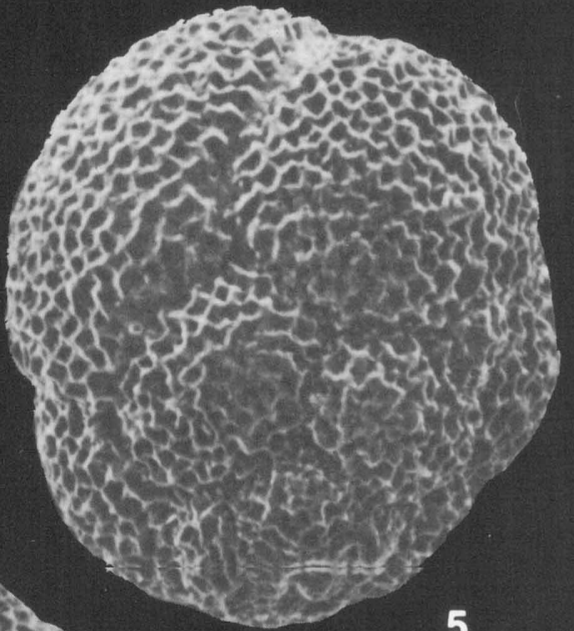

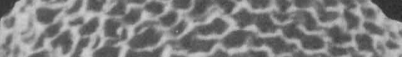

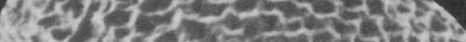

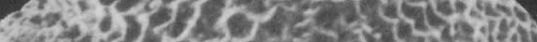

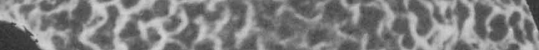

S.

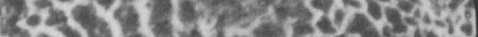

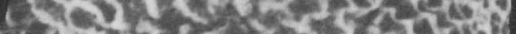

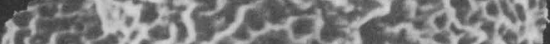

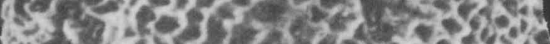

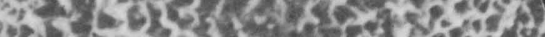

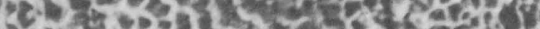

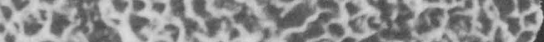

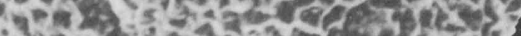

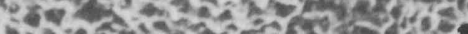

a. 3 in $3=2 \times 4$.

3.

$x^{2}+4 a x^{2}=$ 